\author{
Sribna Y. V. [1; ORCID ID: 0000-0002-6676-0606], \\ Candidate of Economics, Senior Lecturer,

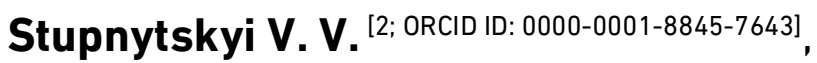 \\ Candidate of Economics (Ph.D.), Associate Professor, \\ Stupnytska N. I. [3; ORCID ID: 0000-0002-4490-1316],
} Lecturer

\author{
${ }^{1}$ National University of Water and Environmental Engineering, Rivne \\ ${ }^{2}$ Dubno Branch Higher Education Institution «Open International University of Human \\ Development «Ukraine», Dubno \\ ${ }^{3}$ Rivne State Humanitarian University, Rivne
}

\title{
SOCIAL ENTREPRENEURSHIP - DEVELOPMENT TRENDS AND EFFICIENCY ANALYSIS IN EU COUNTRIES
}

The study analyses the development of social entrepreneurship in the EU. The state system of its recognition at the legislative level is noted. International standards that allow developing social entrepreneurship and forming a system of its non-financial reporting are analysed. The necessity to take into account the results of these economic entities as a basic basis for the development of socio-cultural sphere and local environmental measures, which guarantees the observance of constitutional social values of citizens, social groups and society in general. The group systems of indicators are described, which allow to estimate both material and monetary contribution to the development of the social and environmental sphere of sustainable development of society. This set of indicators is necessary to assess the effectiveness of social entrepreneurship at the level of the territorial community and the city, and further calculation should be carried out in determining the integrated indicator - the Index of Social Entrepreneurship.

The results of the study can be used to study trends and further development of social entrepreneurship and used in further development of methods for calculating the system of indicators of quality and quantity of implemented social entrepreneurship services, as well as their contribution to sustainable development of EU territories and countries.

Keywords: social entrepreneurship; social cooperative; social entrepreneurship standards; social entrepreneurship indicators; social entrepreneurship index.

Formulation of the problem. The market economy model forms a significant potential for income generation by individual entrepreneurs, 
which is enhanced through the control of market mechanisms. Such control generates corruption schemes in the system of state regulation, and in the business system - the formation of monopoly groups. With such a purely economic approach, quite a number of social problems of society remain out of the attention of businesses and governments. The dismantling of the socialist world system pointed to the complete inability of transition economies to solve social problems, which have become extremely acute.

State regulation of the market economy causes a belated solution to such problems of society, and big business conducts charitable events that are unable to cover all these acute problems. Small business can not fully compete with large, and crises force entrepreneurs to be realized in another area - social. This intertwining of events, interests and participants of society led to the emergence and intensification of social entrepreneurship.

For fifty years, social entrepreneurship has had a wide geography, occupied a significant share of the economic and social sphere of European countries and contributes to the creation of added value of the country. Some indices and indicators have been partially developed, which allow tracking the current state of this phenomenon in general. However, in the global approach, uncertainty does not allow to fully implement the concept of sustainable development.

Analysis of recent research and publications. Foreign scientists J. Thompson, P. Blooom, J. Dees, M. Yunus, M. Sud, T. Komatsu, K. Hockerts, J.Mair, S. Abu-Saifan, Ch. Leadbeater, C. Durkin, and A. Peredo thoroughly researched the issue of social entrepreneurship. However, the latest trends in the world economy are not fully disclosed and not substantiated in practical applications.

Formulating the article goals. The purpose of the article is to study the specifics of social entrepreneurship in EU countries. Accordingly, there are the following tasks:

- to characterize the legislative regulation of social enterprises in the EU;

- to analyze the standards for the formation of the requirements of social entrepreneurship;

- to propose an alternative assessment of social entrepreneurship in the EU.

Outline of the main research material. For European countries, social entrepreneurship is quite a mass phenomenon. Such activities were first legally recognized in Italy with the adoption of Law 381/1991 [1]. It recognized two types of social cooperatives: "A" - social services - 
cooperatives that provide various services at home; day care centers; socio-educational communities; therapeutic communities; houses of residence; nursery. The second type of social integration «B» agriculture; environmental protection; carpentry; computer maintenance and configuration; washing; cleaning; repair of things, printing and stitching of books. Cooperatives with a combination of two forms «A + B» were also widespread.

These social structures had to meet the following requirements:

1. Profits are distributed in accordance with the social goals of the organization.

2. Social cooperatives must develop their own assets.

3. At least $30 \%$ of the members of the cooperative belong to the category of vulnerable citizens.

Law 155/2006 [1] in Italy significantly expanded the concept of social entrepreneurship. The status of social can be obtained by any non-profit enterprise that constantly carries out economic activities and distributes socially significant goods and services. The law also stricter requirements for such companies. For example, they must publish an Annual Sustainable Development Report. At the same time, social enterprises do not receive special benefits, except that they can participate in grant programs.

The following systems of social entrepreneurship in Europe can be distinguished:

1. The Northern Europe model is characterized by active support of the state of the social sphere (Belgium, Sweden, the Netherlands).

2. The Central Europe model - the governments of France, Italy, Portugal are focused on the implementation of targeted social programs and business projects.

3. The Great Britain model, where the priority is social investment.

4. The Eastern Europe model - the development of social entrepreneurship is based on the intensive use of grants and subsidies (Poland, Lithuania, Latvia, and Romania).

At the beginning of 2021, all European countries have their own legislation regulating the activities of social enterprises. The main condition for accounting for social entrepreneurship is its state recognition, so the current legislative field is formed, which provides for state regulation (Table 1 ).

State regulation reflects the specifics of social entrepreneurship in individual EU countries and organizational forms of its implementation. Thus, for Italian and Polish entrepreneurship, the priority is not to make a profit, but social significance. Most Eastern European countries develop social entrepreneurship through a system of programs and foreign grands, in part through religious organizations. 
Table 1

Characteristics of legislative regulation of social enterprises in the EU

\begin{tabular}{|c|c|c|c|}
\hline \begin{tabular}{|c|} 
Organization \\
systems of \\
social \\
entrepre- \\
neurship
\end{tabular} & Countries & Legislation & $\begin{array}{l}\text { Type of social } \\
\text { entrepreneurship }\end{array}$ \\
\hline \multirow{4}{*}{$\begin{array}{l}\text { The Northern } \\
\text { Europe model }\end{array}$} & Belgium & $\begin{array}{l}\text { Article } 661 \text { of the Company Code of } \\
1999\end{array}$ & Social enterprise \\
\hline & Denmark & $\begin{array}{l}\text { Law No.711 of } 25 / 06 / 2014 \text { on } \\
\text { Registered Social Enterprises }\end{array}$ & Social enterprise \\
\hline & Finland & $\begin{array}{l}\text { Law No.1351/2003 of } 30.12 .2003 \\
\text { on Social Enterprises }\end{array}$ & Social enterprise \\
\hline & Luxembourg & $\begin{array}{l}\text { Law of } 12 / 12 / 2016 \text { of Social } \\
\text { impact Societies, or SIS }\end{array}$ & Social enterprise \\
\hline \multirow{4}{*}{$\begin{array}{c}\text { The Central } \\
\text { Europe model }\end{array}$} & Greece & $\begin{array}{l}\text { Law No.2716/1999 and } \\
\text { No.4019/20144 on Social } \\
\text { Cooperatives }\end{array}$ & Social cooperative \\
\hline & France & $\begin{array}{l}\text { Law No.2014/856 of } 31 / 07 / 2014 \\
\text { on the Social and Solidarity } \\
\text { Economy }\end{array}$ & Collective cooperative \\
\hline & Italy & $\begin{array}{l}\text { Law No. } 381 / 1991 \text { on Social } \\
\text { Cooperatives } \\
\text { No.155 of } 24 / 03 / 2006 \text { on Social } \\
\text { Enterprise }\end{array}$ & Social cooperative \\
\hline & Portugal & $\begin{array}{l}\text { Law No.1/2013 of } 29 / 10 / 2013 \text { on } \\
\text { Special Employment Centers }\end{array}$ & Social cooperative \\
\hline \multirow{9}{*}{$\begin{array}{l}\text { The Eastern } \\
\text { Europe model }\end{array}$} & Croatia & $\begin{array}{l}\text { Law No.764 of } 11 / 03 / 2011 \text { on } \\
\text { Cooperatives }\end{array}$ & Social cooperative \\
\hline & Czechia & $\begin{array}{l}\text { Law No.90/2012 on commercial } \\
\text { Companies and Cooperatives }\end{array}$ & Social cooperative \\
\hline & Hungary & Law No.X-2006 on Cooperatives & Social cooperative \\
\hline & Latvia & $\begin{array}{l}\text { Law No.212(6039) of } 2018 \text { on } \\
\text { Social Enterprises }\end{array}$ & Social enterprise \\
\hline & Lithuania & $\begin{array}{l}\text { Law No.IX-2251 of } 1 / 06 / 2004 \text { on } \\
\text { Social Enterprise }\end{array}$ & Social enterprise \\
\hline & Poland & $\begin{array}{l}\text { Law of } 27 / 04 / 2006 \text { on Social } \\
\text { Cooperatives }\end{array}$ & Social cooperative \\
\hline & Romania & $\begin{array}{l}\text { Law No.219 of } 23 / 07 / 2015 \text { on the } \\
\text { Social Economy }\end{array}$ & Social enterprise \\
\hline & Slovakia & $\begin{array}{l}\text { Law No. } 5 / 2004 \text { of } 04 / 12 / 2003 \text { on } \\
\text { Employment Services }\end{array}$ & Social enterprise \\
\hline & Slovenia & $\begin{array}{l}\text { Law no.20 of } 2011 \text { on Social } \\
\text { Entrepreneurship }\end{array}$ & Social enterprise \\
\hline \begin{tabular}{|c|} 
The Great \\
Britain model
\end{tabular} & Great Britain & $\begin{array}{l}\text { Law No.1788 of } 2005 \text { on } \\
\text { Community Interest Company } \\
\text { Regulations }\end{array}$ & $\begin{array}{l}\text { Organization with the } \\
\text { interests of territorial } \\
\text { communities }\end{array}$ \\
\hline
\end{tabular}

Source: Compiled by authors on the data of European Commission [2]

State regulation reflects the specifics of social entrepreneurship in 
individual EU countries and organizational forms of its implementation. Thus, for Italian and Polish entrepreneurship, the priority is not to make a profit, but social significance. Most Eastern European countries develop social entrepreneurship through a system of programs and foreign grants, in part through religious organizations.

Social entrepreneurship is a dynamic complex system designed to implement the constitutionally guaranteed social values of citizens, social groups and society as a whole through public authorities, local governments and specialized institutions of social responsibility. The implementation of these values requires an assessment of social entrepreneurship, taking into account the specifics of individual countries and regions. Quantitative and qualitative approaches are used.

The assessment of social entrepreneurship is based on the international system of regulation of social and labor relations, initiated by the UN through the global treaty of the UN General Assembly, which unites more than 8,000 participants (including 6,000 - business representatives) from 135 countries [3].

This contractual framework is focused on the protection of human rights, labor relations, environmental protection and anti-corruption. The implementation of the UN General Assembly involves the implementation of the following principles:

1. Respect, support, observance of human rights, freedom of association and not hindering the conclusion of collective agreements.

2. Prevention of forced labor, discrimination in labor relations and complete prohibition of child labor.

3. Counteracting all forms of corruption.

4. Active support of environmental concept and safety.

Implementation of these principles orients entrepreneurs to economic, social and environmental responsibility.

Social enterprises, regardless of the field of activity, are obliged to prepare and submit to interested users financial statements, which reflect complete, truthful and unbiased information about the financial condition and results of the enterprise for the reporting period.

In addition to financial statements, the social enterprise compiles and publishes non-financial statements detailing the responsibility of the social entrepreneurship entity for employment and social responsibility (protection of human rights, fight against corruption and bribery); implementation of environmental measures; introduction of due diligence (assessment of investment risks, independent assessment of the investment object, comprehensive study of the company's activities, comprehensive review of its financial condition and market position). For large enterprises, the need for non-financial reporting is regulated by Directive 2014/95 / EU of 22 October 2014 [4]. 
Directives 2013/34 / EU (paragraph 19a.1 of Article 19a) [5] provided information unification and structuring of non-financial reporting, developed requirements and relevant standards. Social enterprises with more than 500 employees must include non-financial information in the Management Report, in particular on the activities of the enterprise, at least in the following aspects: environmental, social, employment, anti-corruption and bribery, human rights.

Subsequently, a series of standards was developed and proposed, covering social partnership activities in key areas. The most common reporting standards are: ISO 14000, Social Accountability 8000 (SA 8000), Account Ability 1000 (AA 1000) i Global Reporting Initiative (GRI) (table. 2). Thus, a fairly broad system of standards for assessing social partnership has been developed. The standards are focused on meeting the requirements for greening modern production and meeting the requirements for the protection of workers' rights, most provide requirements and methods for non-financial reporting of business structures and relate to their management of different sizes and geographies. If the beginning of the standardization system was focused on large business entities, now it covers small businesses and organizations of various forms of ownership and subordination. However, they are not yet generally binding.

Table 2

Characteristics of current standards for the formation of requirements and reporting of social entrepreneurship

\begin{tabular}{|c|c|c|}
\hline $\begin{array}{l}\text { Group of } \\
\text { standards }\end{array}$ & Name & Characteristic \\
\hline \multicolumn{3}{|c|}{ ISO 14000} \\
\hline $\begin{array}{c}\text { ISO } \\
14001: 2004\end{array}$ & $\begin{array}{l}\text { Environmental management } \\
\text { systems. Requirements with } \\
\text { guidance for use }\end{array}$ & $\begin{array}{l}\text { Aimed at the functioning of } \\
\text { environmental management systems } \\
\text { of organizations }\end{array}$ \\
\hline $\begin{array}{c}\text { ISO } \\
14001: 2015\end{array}$ & $\begin{array}{l}\text { Environmental management } \\
\text { systems - Requirements } \\
\text { with guidance for use }\end{array}$ & $\begin{array}{l}\text { Assisting organizations in the sound } \\
\text { performance of their environmental } \\
\text { responsibilities on a systematic basis }\end{array}$ \\
\hline $\begin{array}{c}\text { ISO } \\
14004: 2016\end{array}$ & $\begin{array}{l}\text { Environmental management } \\
\text { systems - General } \\
\text { guidelines on } \\
\text { implementation }\end{array}$ & $\begin{array}{l}\text { It is of a recommendatory nature and } \\
\text { can be applied to any organization, } \\
\text { regardless of its size, type, location } \\
\text { and level of maturity. }\end{array}$ \\
\hline ISO 14015 & $\begin{array}{l}\text { Environmental management } \\
\text { - Environmental } \\
\text { assessment of sites and } \\
\text { organizations }\end{array}$ & $\begin{array}{l}\text { Establishes guidance in the process } \\
\text { of identifying environmental aspects } \\
\text { and environmental findings and } \\
\text { provides identification of their } \\
\text { implications for business }\end{array}$ \\
\hline
\end{tabular}


Continuation of Table 2

\begin{tabular}{|c|c|c|}
\hline ISO 14020 & $\begin{array}{l}\text { "Environmental labels and } \\
\text { declarations - General } \\
\text { principles }\end{array}$ & $\begin{array}{l}\text { Establishes the principles to be } \\
\text { followed in the development and use } \\
\text { of eco-labels and declarations }\end{array}$ \\
\hline ISO 14031 & $\begin{array}{c}\text { Environmental management } \\
\text { - Environmental } \\
\text { performance evaluation - } \\
\text { Guidelines }\end{array}$ & $\begin{array}{c}\text { Establishes an environmental } \\
\text { assessment that allows organizations } \\
\text { to measure and evaluate } \\
\text { environmental performance and } \\
\text { share data on the issue using key } \\
\text { performance indicators }\end{array}$ \\
\hline ISO 14040 & $\begin{array}{l}\text { Environmental Management } \\
\text { - Life cycle assessment - } \\
\text { Principles and framework }\end{array}$ & $\begin{array}{l}\text { Describes the general structure, } \\
\text { principles and requirements for life } \\
\text { cycle assessment research }\end{array}$ \\
\hline SO 14050 & $\begin{array}{c}\text { Environmental management } \\
\text { - Vocabulary }\end{array}$ & $\begin{array}{c}\text { The standard defines the basic } \\
\text { concepts related to the environmental } \\
\text { activities of organizations, published } \\
\text { in a series of international standards } \\
\text { ISO } 14000\end{array}$ \\
\hline ISO 14062 & $\begin{array}{l}\text { Environmental management } \\
\text { - Integrating environmental } \\
\text { aspects into product design } \\
\text { and development }\end{array}$ & $\begin{array}{l}\text { describes the concepts and existing } \\
\text { methods related to the integration of } \\
\text { environmental aspects in product } \\
\text { design and development, where } \\
\text { «products» means both goods and } \\
\text { services }\end{array}$ \\
\hline ISO 14063 & $\begin{array}{l}\text { Environmental management } \\
\text { - Environmental } \\
\text { communication - Guidelines } \\
\text { and example }\end{array}$ & $\begin{array}{l}\text { establishes recommendations for } \\
\text { organizations on the basic principles, } \\
\text { policies, strategies and activities } \\
\text { related to internal and external } \\
\text { limited environmental information. }\end{array}$ \\
\hline ISO 14064 & $\begin{array}{c}\text { Organization Quantification } \\
\text { and Reporting of Green } \\
\text { House Gases }\end{array}$ & $\begin{array}{c}\text { provides governments, businesses, } \\
\text { regions, and other organizations with } \\
\text { an additional set of program tools for } \\
\text { quantifying, monitoring, reporting, } \\
\text { and verifying greenhouse gas } \\
\text { emissions }\end{array}$ \\
\hline \multicolumn{3}{|c|}{ OHSAS 18000} \\
\hline $\begin{array}{l}\text { BS OHSAS } \\
18001: 2007\end{array}$ & $\begin{array}{l}\text { Occupational health and } \\
\text { safety management } \\
\text { systems - Requirements }\end{array}$ & $\begin{array}{l}\text { aimed at identifying hazards, } \\
\text { assessing and managing risks in the } \\
\text { field of health and safety related to } \\
\text { the activities of the organization }\end{array}$ \\
\hline $\begin{array}{l}\text { BS OHSAS } \\
18002: 2008\end{array}$ & $\begin{array}{l}\text { Occupational health and } \\
\text { safety management } \\
\text { systems - guidelines for the } \\
\text { implementation }\end{array}$ & $\begin{array}{l}\text { evaluates activities in the field of } \\
\text { health and safety, gives general } \\
\text { advice on the application OHSAS } \\
\text { 18001: } 2007\end{array}$ \\
\hline $\begin{array}{l}\text { BS OHSAS } \\
18004: 2008\end{array}$ & $\begin{array}{l}\text { Guide to achieving effective } \\
\text { occupational health and } \\
\text { safety performance }\end{array}$ & $\begin{array}{l}\text { provides general assistance in the } \\
\text { development, implementation and } \\
\text { improvement of the occupational } \\
\text { safety and health management } \\
\text { system and demonstrates examples } \\
\text { of successful implementation of } \\
\text { activities in accordance with the } \\
\text { requirements BS OHSAS 18001: } 2007\end{array}$ \\
\hline
\end{tabular}


Continuation of Table 2

\begin{tabular}{|c|c|c|}
\hline \multicolumn{3}{|c|}{ Account Ability 1000} \\
\hline AA1000APS & $\begin{array}{c}\text { Accountability Principles } \\
\text { Standard }\end{array}$ & $\begin{array}{l}\text { is the basis for companies to identify } \\
\text { and identify the most important } \\
\text { issues in the field of sustainable } \\
\text { development and respond to them }\end{array}$ \\
\hline AA1000AS & Assurance Standard & $\begin{array}{l}\text { provides a methodology for } \\
\text { assessing the level of compliance } \\
\text { with the basic principles of the } \\
\text { Account Ability standard, on which } \\
\text { the accountable companies are. }\end{array}$ \\
\hline AA1000SES & $\begin{array}{c}\text { Stakeholder Engagement } \\
\text { Standard }\end{array}$ & $\begin{array}{l}\text { sets guidelines for the organization } \\
\text { of the process of interaction with } \\
\text { stakeholders in order to achieve } \\
\text { managed, predictable and } \\
\text { sustainable results to improve } \\
\text { efficiency in the field of CSR. }\end{array}$ \\
\hline \multicolumn{3}{|c|}{ SA 8000} \\
\hline $\begin{array}{c}\text { SA } \\
8000: 2008\end{array}$ & $\begin{array}{c}\text { Social } \\
\text { Accountability International }\end{array}$ & $\begin{array}{l}\text { establishes social responsibility and } \\
\text { obligations of the organizations } \\
\text { before the personnel and all society, } \\
\text { defines conditions of introduction of } \\
\text { social qualities of rendering of work }\end{array}$ \\
\hline \multicolumn{3}{|c|}{ Global Reporting Initiative (GRI) } \\
\hline GRI 101 & Foundation & \multirow{2}{*}{$\begin{array}{l}\text { Used to simplify the process of } \\
\text { publishing a report by companies }\end{array}$} \\
\hline GRI 102 & General Disclosures & \\
\hline GRI 103 & Impact Standards & $\begin{array}{l}\text { focused on large enterprises, meets } \\
\text { the needs of a wide range of } \\
\text { stakeholders - employees, } \\
\text { consumers of products and services, } \\
\text { local communities }\end{array}$ \\
\hline
\end{tabular}

Source: Compiled by authors on the base of [6-10]

The most well-known index is the Sustainable Development Index. The method of calculating this indicator is carried out in three main areas: meeting basic needs, welfare and prospects of the country. 52 separate indicators are used in the calculation. They compare the level of development of countries with the same GDP in absolute and relative terms. This index allows a comprehensive assessment of the country's economic, social and environmental public policy.

For large corporations whose shares are traded on the stock exchange, their indicator is the MSCI KLD 400 index. It allows companies to further increase the profitability of their shares. By 2020, this index has increased stock returns for Microsoft (MSFT), Facebook (FB) and Alphabet (GOOG). 
In terms of content, the MSCI KLD 400 social index is a stock index for companies that guarantee a reputation for social and environmental responsibility and maintain high environmental, social and corporate standards (ESG). In fact, it represents 400 public companies that maintain high ESG ratings.

Another index is the FTSE4 Good index. It is a series of ethical investment stock market indices launched in 2001 by the FTSE Group and supported by the Ethical Investment Research Service (EIRIS). However, this is a rather conditional index, as it does not have accurate financial information that the portfolio of companies that differ in ethical criteria has a significant equivalent in their market valuation compared to other companies.

After the financial crisis of 2009, a group of philanthropists, politicians and social entrepreneurs led by Michael Porter - Social Progress Imperative; they argue that modern economic development is a consequence of bad capitalism, in which the social sphere is not focused on long-term environmental and social achievements and exacerbates social and economic inequalities. Therefore, in 2013, Social Progress Imperative proposed a measure of its index - SPI. It is designed to assess only social progress - separately from economic indicators, which allows you to assess all areas of life and all countries through the criterion of return on the economy.

A separate group are indices that reflect the quality and standard of living of the population. This evaluation system has been evolving since the $1950 \mathrm{~s}$. At the initial stage, the indicators of social accounts were used in the calculation method. In the $1960 \mathrm{~s}$, the first sets of social indicators were formed to assess social programs and social policy of the state. In the 1970s, a set of social indicators was developed and general requirements for the system of social indicators were formed. And since the 1990s, various studies on social development and quality of life of the population have been launched, and then various integrated indicators have appeared.

We offer an assessment of social entrepreneurship through changes in official statistics, which will allow us to track trends in the change of general, socio-cultural and environmental effects. Accordingly, we present a system that more fully reflects the specifics of social entrepreneurship (Figure). 
Structural assessment of the development of society through social entrepreneurship of a separate territory

\begin{tabular}{|c|c|c|c|}
\hline $\begin{array}{l}\text { Ecological } \\
\text { component }\end{array}$ & $\begin{array}{l}\text { 1. Environmental load } \\
\text { 2. Environmental support of public utilities } \\
\text { 3. Ecological landscape and infrastructure }\end{array}$ & \multirow{3}{*}{ 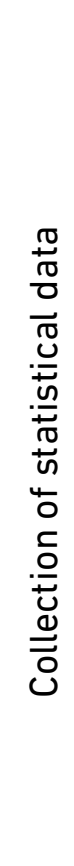 } & \multirow{3}{*}{ 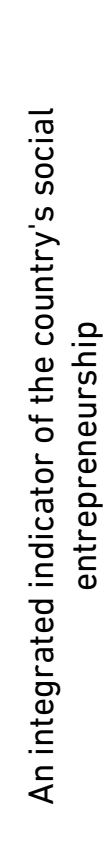 } \\
\hline $\begin{array}{l}\text { Economic } \\
\text { component }\end{array}$ & $\begin{array}{l}\text { 1. Investments } \\
\text { 2. Taxes } \\
\text { 3. Charitable contributions } \\
\text { 4. The level of wages } \\
\text { 5. Budget revenues / expenditures } \\
\text { 6. The volume of sales of goods and services }\end{array}$ & & \\
\hline $\begin{array}{l}\text { Socio- } \\
\text { cultural } \\
\text { component }\end{array}$ & $\begin{array}{l}\text { 1. Socio-cultural infrastructure } \\
\text { 2. Social expenditures } \\
\text { 3. Demographic indicators } \\
\text { 4. Education } \\
\text { 5. Healthcare }\end{array}$ & & \\
\hline
\end{tabular}

Figure. Logical scheme for assessing social entrepreneurship Source: Created by authors

The concretization of the relevant three components (environmental, economic and socio-cultural) is presented in table. 3.

Table 3

Specification of indicators for the assessment of social entrepreneurship

\begin{tabular}{|l|l|c|}
\hline Component & \multicolumn{1}{|c|}{ Indicators } & $\begin{array}{c}\text { Unit of } \\
\text { measurement }\end{array}$ \\
\hline \multirow{4}{*}{ Economic } & The amount of funding raised & million euros \\
\cline { 2 - 3 } & Total authorized capital & million euros \\
\cline { 2 - 3 } & Volume of sales, services & million euros \\
\cline { 2 - 3 } & $\begin{array}{l}\text { Financial result (enterprise profits } \\
\text { amount) before tax }\end{array}$ & million euros \\
\cline { 2 - 3 } & Volume of taxes & million euros \\
\cline { 2 - 3 } & Net profit & million euros \\
\cline { 2 - 3 } & $\begin{array}{l}\text { GDP growth per capita (specify by social } \\
\text { groups) }\end{array}$ & euros \\
\cline { 2 - 3 } & $\begin{array}{l}\text { Number of subjects of social } \\
\text { entrepreneurship }\end{array}$ & units \\
\hline
\end{tabular}


Continuation of Table 3

\begin{tabular}{|c|c|c|}
\hline & $\begin{array}{l}\text { The ratio of the minimum wage to the } \\
\text { value of the consumer basket }\end{array}$ & \\
\hline & $\begin{array}{l}\text { Revenues of the general fund of the city / } \\
\text { community budget }\end{array}$ & million euros \\
\hline & Number of employees & person \\
\hline & The level of the minimum wage & euros \\
\hline & The level of the maximum wage & euros \\
\hline & The ratio of maximum and minimum wage & euros \\
\hline & Salary fund & million euros \\
\hline & Injury level & \\
\hline & The level of occupational diseases & \\
\hline & Level of temporary disability & \\
\hline & The level of housing & \\
\hline & Level of education and qualification & \\
\hline Socio- & Homeless points & units \\
\hline & Number of divorces & person \\
\hline & Number of orphans & person \\
\hline & Number of seriously ill people & person \\
\hline & Dynamics of migration & \\
\hline & $\begin{array}{l}\text { Overhaul of residential, social and } \\
\text { residential complex }\end{array}$ & \\
\hline & Introduction of infrastructure complexes & \\
\hline & $\begin{array}{l}\text { Provision of housing for the population, on } \\
\text { average per person, }\end{array}$ & $\mathrm{m}^{2}$ \\
\hline & $\begin{array}{l}\text { Number of persons studying in } \\
\text { educational institutions }\end{array}$ & Person \\
\hline Ecological & $\begin{array}{l}\text { Investment in solving environmental } \\
\text { problems }\end{array}$ & thousand euros \\
\hline & $\begin{array}{l}\text { Number of public organizations for nature } \\
\text { protection }\end{array}$ & units \\
\hline & $\begin{array}{l}\text { Emissions of pollutants into the } \\
\text { atmosphere }\end{array}$ & tonn \\
\hline & $\begin{array}{l}\text { Discharge of polluted return waters into } \\
\text { natural surface water bodies, }\end{array}$ & million $\mathrm{m}^{2}$ \\
\hline & Waste generation of I-III hazard classes, & tonn \\
\hline & $\begin{array}{l}\text { Number of vehicles (road transport and } \\
\text { electric transport), }\end{array}$ & thousand units \\
\hline
\end{tabular}

Source: Created by authors

This set of indicators is necessary to assess the effectiveness of social entrepreneurship at the level of the community and the city, and further calculation should be made in determining the integrated indicator - Social Entrepreneurship Index, which is determined by the general method of determining any indices, but differs in number and 198 
specification of indicators. In scientific terms, social entrepreneurship is explained as a consequence of the system of capitalism and market economy, the lack of interest in solving rather small but significant social problems of the community in the territories of residence. Such a mass movement at the local level necessitated its state recognition and support. Therefore, governments adopt appropriate legislation and recognize this entrepreneurship as a necessary condition for solving social local problems.

\section{Conclusion}

From the standpoint of big business, the socio-environmental problems of society are manifested in the implementation of mandatory international norms and requirements. Therefore, certain standards have been formed, which put forward the need for certification of the system not only of their products, but also working conditions and ways to implement these requirements. Thus, a system of non-financial reporting has been formed, which is not mandatory, but is actively used by large companies to strengthen their public perception and increase their competitiveness in the market. This approach has created the need for a stock assessment of corporate social responsibility. At the same time, the global problem of sustainable development has put forward the need to develop and apply a quantitative and qualitative assessment of the development of countries using indicators of social and environmental nature. In addition, social entrepreneurship requires an assessment of both the activities and the consequences of these activities. Therefore, accounting and analysis of the work of these entities has become the object of scientific study. As a result, it is not the financial reporting of this business that has become the basis of the reporting system that is legally recognized in many EU countries. However, many aspects and especially the consequences of entrepreneurship remain out of consideration in these reports.

1. European Commission (2020) Social enterprises and their ecosystems in Europe. Updated country report: Italy. Author: Carlo Borzaga. Luxembourg: Publications Office of the European Union. URL: https://europa.eu/!Qq64ny (accessed: 18.03.2021). 2. European Commission (2020) Social enterprises and their ecosystems in Europe. Comparative synthesis report. Authors: Carlo Borzaga, Giulia Galera, Barbara Franchini, Stefania Chiomento, Rocío Nogales and Chiara Carini. Luxembourg: Publications Office of the European Union. URL: https://europa.eu/!Qq64ny (accessed: 18.03.2021). 3. The official website of UN General Assembly. URL: https://www.un.org/en/ga/ (accessed: 18.03.2021). 4. DIRECTIVE 2013/34/EU OF THE EUROPEAN PARLIAMENT AND OF THE COUNCIL of 26 June 2013 on the annual financial statements, consolidated financial statements and related reports of certain types of undertakings, amending Directive 2006/43/EC of the European Parliament and of the Council and repealing Council Directives 78/660/EEC and 83/349/EEC. 5. DIRECTIVE 2014/95/EU OF THE EUROPEAN PARLIAMENT AND OF THE COUNCIL of 22 October 2014 amending Directive 2013/34/EU as regards disclosure of nonfinancial and diversity information by certain large undertakings and groups. 6 . The 
official website of ISO. URL: https://www.iso.org/ru/home.html (accessed: 18.03.2021). 7. The official website of OHSAS. URL: https://www.bsigroup.com/enGB/ohsas-18001-occupational-health-and-safety/ (accessed: 18.03.2021). 8. The official website of Account Ability URL: https://www.accountability.org/standards/ 9. The official website of Social Accountability International URL: https://sa-intl.org/ (accessed: 18.03.2021). 10. The official website of Global Reporting Initiative (GRI). URL: https://www.globalreporting.org/ (accessed: 18.03.2021).

\section{REFERENCES:}

1. European Commission (2020) Social enterprises and their ecosystems in Europe. Updated country report: Italy. Author: Carlo Borzaga. Luxembourg: Publications Office of the European Union. URL: https://europa.eu/!Qq64ny (accessed: 18.03.2021). 2. European Commission (2020) Social enterprises and their ecosystems in Europe. Comparative synthesis report. Authors: Carlo Borzaga, Giulia Galera, Barbara Franchini, Stefania Chiomento, Rocío Nogales and Chiara Carini. Luxembourg: Publications Office of the European Union. URL: https://europa.eu/!Qq64ny (accessed: 18.03.2021). 3. The official website of UN General Assembly. URL: https://www.un.org/en/ga/ (accessed: 18.03.2021). 4. DIRECTIVE 2013/34/EU OF THE EUROPEAN PARLIAMENT AND OF THE COUNCIL of 26 June 2013 on the annual financial statements, consolidated financial statements and related reports of certain types of undertakings, amending Directive 2006/43/EC of the European Parliament and of the Council and repealing Council Directives 78/660/EEC and 83/349/EEC. 5. DIRECTIVE 2014/95/EU OF THE EUROPEAN PARLIAMENT AND OF THE COUNCIL of 22 October 2014 amending Directive 2013/34/EU as regards disclosure of nonfinancial and diversity information by certain large undertakings and groups. 6. The official website of ISO. URL: https://www.iso.org/ru/home.html (accessed: 18.03.2021). 7. The official website of OHSAS. URL: https://www.bsigroup.com/enGB/ohsas-18001-occupational-health-and-safety/ (accessed: 18.03.2021). 8. The official website of Account Ability URL: https://www.accountability.org/standards/ 9. The official website of Social Accountability International URL: https://sa-intl.org/ (accessed: 18.03.2021). 10. The official website of Global Reporting Initiative (GRI). URL: https://www.globalreporting.org/ (accessed: 18.03.2021).

Срібна Є. B. ${ }^{[1 ; 0 R C I D ~ I D: ~ 0000-0002-6676-0606], ~}$ к.е.н., старший викладач, Ступницький В. В. [2; ORCID ID: 0000-0001-8845-7643], к.е.н ., доцент, Ступницька Н. I. [3; ORCID ID: 0000-0002-4490-1316],

викладач

${ }^{1}$ Національний університет водного господарства та природокористування, м. Рівне ${ }^{2}$ Дубенська філія вищого навчального закладу «Відкритий університет розвитку людини «Україна», м. Дубно

${ }^{3}$ Рівненський державний гуманітарний університет, м. Рівне

\section{СОЦІАЛЬНЕ ПІДПРИЄМНИЦТВО - ТЕНДЕНЦІЇ РОЗВИТКУ ТА АНАЛІЗ ЕФЕКТИВНОСТІ В КРАÏHАХ ЄС}


підприємництва в країнах ЄС. Відзначена державна система його визнання на законодавчому рівні. Доведено, що соціальне підприємництво в країнах ЄС суттєво відрізняється, тому виділено такі системи організації соціального підприємництва, як модель Північної Європи, модель Центральної Європи, модель Східної Європи та модель Великобританії, кожна з яких має свої специфічні ознаки.

Проаналізовано міжнародні стандарти, які дозволяють розвивати соціальне підприємництво та формувати систему його нефінансової звітності. Вказано, що стандарти орієнтовані на виконання вимог щодо екологізації сучасного виробництва та виконання вимог у захисті прав працівників і стосуються їх менеджменту. Виокремлено міжнародні стандарти, які стосуються регулювання діяльності суб'єктів соціального підприємництва: ISO 14000, OHSAS 18000, Account Ability 1000, SA 8000, Global Reporting Initiative (GRI).

Доведено необхідність обліку результатів діяльності цих суб'єктів господарювання як базової основи розбудови соціокультурної сфери та локальних природоохоронних заходів, що гарантує дотримання конституційних соціальних цінностей громадянами, соціальними групами та суспільством загалом. Охарактеризовані групові системи показників, які дозволяють оцінити як матеріальний, так і грошовий внесок у розбудову соціальної та природоохоронної сфери сталого розвитку суспільства. Цей набір показників є необхідно допустимим для оцінки ефективності діяльності соціального підприємництва на рівні територіальної громади та міста, а подальший розрахунок повинен проводитись у визначенні інтегрального показника - Індексу соціального підприємництва.

Результати дослідження можуть бути використані для вивчення тенденцій та подальшого розвитку соціального підприємництва та застосовані у подальших розробках методик обрахунку системи показників якості та кількості реалізованих послуг соціального підприємництва, а також їх внесок у формування сталого розвитку територій і країн ЄC.

Ключові слова: соціальне підприємництво; соціальний кооператив; стандарти соціального підприємництва; показники соціального підприємництва; індекс соціального підприємництва. 
Ступницкий В. В. ${ }^{[2 ;}$ ORCID ID: 0000-0001-8845-7643],

К.э.Н., доцент,

Ступницкая Н. И. [3; ORCID ID: 0000-0002-4490-1316], преподаватель

\author{
${ }^{1}$ Национальный университет водного хозяйства и природопользования, г. Ровно \\ ${ }^{2}$ Дубенский филиал высшего учебного заведения «Открытый международный \\ университет развития человека» Украина», г. Дубно \\ ${ }^{3}$ Ровенский государственный гуманитарный университет, г. Ровно
}

\title{
СОЦИАЛЬНОЕ ПРЕДПРИНИМАТЕЛЬСТВО - ТЕНДЕНЦИИ РАЗВИТИЯ И АНАЛИЗ ЭФФЕКТИВНОСТИ В СТРАНАХ ЕС
}

В исследовании проанализированы развертывание социального предпринимательства в странах ЕС. Отмечена государственная система его признание на законодательном уровне. Проанализированы международные стандарты, которые позволяют развивать социальное предпринимательство и формировать систему его нефинансовой отчетности. Доказана необходимость учета результатов деятельности этих субъектов хозяйствования как базовой основы развития социокультурной сферы и локальных природоохранных мероприятий, гарантирует соблюдение конституционных социальных ценностей гражданам, социальным группам и обществу в целом. Охарактеризованы групповые системы показателей, позволяющих оценить как материальный, так и денежный вклад в развитие социальной и природоохранной сферы устойчивого развития общества. Этот набор показателей является необходимо допустимым для оценки эффективности деятельности социального предпринимательства на уровне территориальной общины и города, а дальнейший расчет должен проводиться в определении интегрального показателя - индекса социального предпринимательства.

Результаты исследования могут быть использованы для изучения тенденций и дальнейшего развития социального предпринимательства и применены в дальнейших разработках методик расчета системы показателей качества и количества реализованных услуг социального предпринимательства, а также их вклад в формирование устойчивого развития территорий и стран ЕС.

Ключевые слова: социальное предпринимательство; социальный кооператив; стандарты социального предпринимательства; показатели социального предпринимательства; индекс социального предпринимательства. 